Article

\title{
Complementary Development between China and Sub-Sahara Africa: Examining China's Mining Investment Strategies in Africa
}

\author{
Xiaoliang Wang ${ }^{1}$, Danlin Yu ${ }^{2,3, *}$ and Chunhua Yuan ${ }^{4}$ \\ 1 School of Management, China University of Mining and Technology-Beijing, Beijing 100083, China; \\ bqt1700502017@student.cumtb.edu.cn \\ 2 School of Sociology and Population Studies, Renmin University of China, Beijing 100872, China \\ 3 Department of Earth and Environmental Studies, Montclair State University, Montclair, NJ 07043, USA \\ 4 Center for Development and Research, China Geological Survey, Beijing 100037, China; \\ ychunhua@mail.cgs.gov.cn \\ * Correspondence: yud@mail.montclair.edu
}

Citation: Wang, X.; Yu, D.; Yuan, C. Complementary Development between China and Sub-Sahara Africa: Examining China's Mining Investment Strategies in Africa. Sustainability 2021, 13, 11678. https:// doi.org/10.3390/su132111678

Academic Editor: Malgorzata Jasiulewicz-Kaczmarek

Received: 21 September 2021

Accepted: 19 October 2021

Published: 22 October 2021

Publisher's Note: MDPI stays neutral with regard to jurisdictional claims in published maps and institutional affiliations.

Copyright: (c) 2021 by the authors. Licensee MDPI, Basel, Switzerland. This article is an open access article distributed under the terms and conditions of the Creative Commons Attribution (CC BY) license (https:// creativecommons.org/licenses/by/ $4.0 /)$.

\begin{abstract}
China's recent national and international regional development strategies emphasize both the deepening of the domestic market and the exploration of new markets and resource suppliers to support China's industrialization. The cooperation with, and investment in, Africa has become an integrated part of China's international regional development strategy. Investment in Africa is often the result of a decision process that requires balance among local complex political, economic, social, and geological conditions. Proper decision support analysis is the key for success or failure of complementary development. Based on location theories, the current study analyzes China's mining investment in Africa and derives a set of indicators to form the basis for evaluating China's investment strategies in the mining industries in Africa. A multi-criteria decision making (MCDM) approach, the VIKOR method, is applied to evaluate six African countries based on this set of indicators. Results suggest that while resource abundance and value are important factors for mining investment decisions, political stability and local legal system restrictions are weightier in the decision-making process. China's outward foreign direct investment (OFDI) in mining industries in Africa is more inclined to countries with stable political environment, resource endowment and greater value advantage so that both parties can maximize the benefits from such investment.
\end{abstract}

Keywords: complementary development; mining investment; investment decision support; AHP; VIKOR; China

\section{Introduction}

The rapid development of China has attracted scholarly attention from a variety of fields during the past decades [1-9]. China's economy has reached the point that global investment has become an integrated part of China's economic development. The recently issued fourteenth "Five-Year Plan" points out that China's economic development now turns from high-speed growth to high-quality growth. The current priorities for China's economic development are to optimize economic structures, balance regional development inequality, boost economic and technological creativity, and increase the degree of China's opening-up, specifically in the field of global investment.

Global investment is an integral part of globalization. Globalization has been regarded as an effective way to re-organize production factors (labor and capital), to increase those factors' productivity through international trade and global investment and to speed up the investing country's economic development [10-13]. Utesch-Xiong [14] studied China's foreign direct investment policies in transnational acquisition, suggesting that China's global investment is composed of both private enterprise-led and government-led investments, but is primarily dominated by government-led investments. In the past decade, China 
has intensified its OFDI all over the world after it launched the Belt and Road Initiative (BRI)-sometimes called the One Belt, One Road (OBOR) initiative [15]. Central Asia is one of the primary spots of interest for China's OFDI during this period because the Belt and Road Initiative started from the ancient "Silk Road" that connects China and Europe through central Asia [14,16-18]. Africa is a strategic location for China's OFDI considering the abundant natural resources in this continent [19]. China's interests in investing in Africa have grown during the past decades primarily because China and Africa are highly complementary to each other. China and Africa are in different stages of industrialization. For the past decades, China has developed to late stages of industrialization with mature technology, relatively complete industrial system, and accumulated sufficient skilled labor and capital. Still, to support China's further industrialization, the demand for raw minerals and other materials is large [20-24]. Africa, on the other hand, is in the initial stages of industrialization, hence it has a strong demand for technology, skilled labor and investment to support its industrialization and economic development. Africa is also abundant in various mineral resources because of its long-term geological stability. From both the industrial structure and mineral reserve perspectives, China's OFDI to Africa, especially in the mining industries could result in mutually beneficial relationships. As a matter of fact, Africa ranked second after Asia-Pacific regions as a destination for China's OFDI in the mining industries, based on the Standard and Poor's Global Market Intelligence database (Figure 1).

Asia-Pacific,50\%

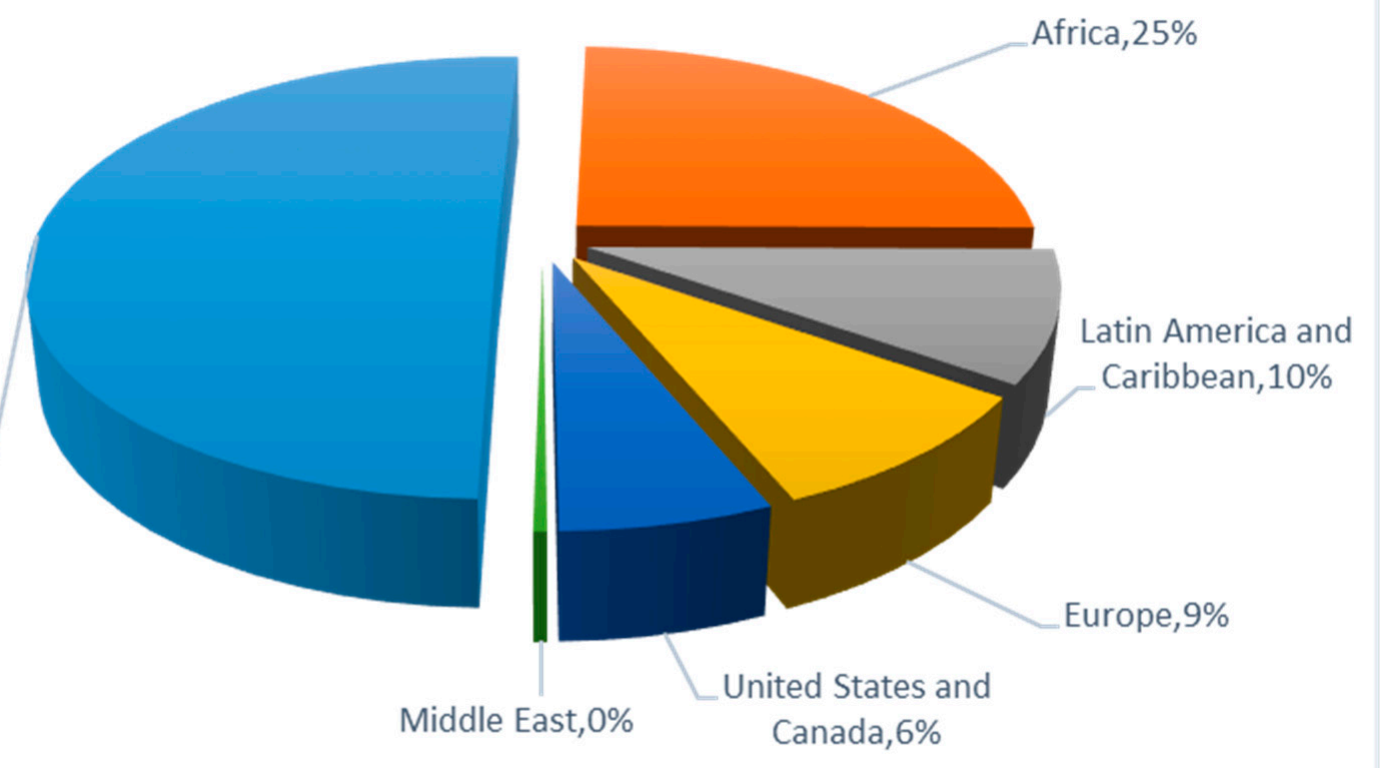

Figure 1. China's global OFDI in the mining industry.

However, direct investment in African countries is often hindered by the complex local geological conditions, survey completeness, higher risk of failure, and relatively lower input-output ratio. Moreover, the often unstable social and political conditions in many African countries and the lower level of overall socioeconomic development could pose a higher risk for any foreign investment there. Local communities' responses to foreign investment, particularly in mining industries, are far from friendly. In fact, Christensen [25] analyzed the number of mining projects and corresponding number of protests or even riots in many African countries south of the Sahara, and concluded that the increase in mining projects in the region could potentially bring twice as many protests or riots that would 
disrupt normal operations of the mining industries. Apparently, higher outputs come with higher risk. This causes risk analysis and evaluation when investing in African countries' mining industries a necessity prior to any meaningful investment. Based on the Standard and Poor's Global Market Intelligence database, at the time this study was conducted, there were 3749 investment projects in Africa's mining industries from 48 countries or places. Of these, China only invested in 123 projects, covering 25 countries, and focusing primarily on Tanzania, Congo (Kinshasa), Mozambique, and South Africa.

As China's industrialization continues and economy grows, China will undoubtedly seek to invest more into the mining industries in Africa. Evaluating the risks and potential input-output ratio of such investments prior to the actual operation has become increasingly important for intelligent decision making. Lu and Liu [19] investigated the relationship between China's OFDI and Africa's manufacturing industry. While witnessing a great improvement in Africa's economic performance recently, they also argued that the lagging level of industrialization hinders further investment since investing in the mining industries does not operate in a vacuum. Without sufficient supplementary supports from up- and down- stream industries and infrastructure, investing in mining industries could be prohibitively costly. The current study collects both interested stakeholders' opinions through an intensive survey and a relatively holistic profile of candidate countries in Africa to generate a realistic assessment system regarding China's OFDI in mining industries. We attempt to recognize important factors that determine China's investment with the current study. Through applying an expert-supported weighting scheme (the analytical hierarchical processing method), this study employs a multi-criteria decision making (MCDM) approach, the VIKOR (in Serbian: VIseKriterijumska Optimizacija I Kompromisno Resenje) method, to build an investment decision-making model. The analysis is intended to provide not only decision support for China's investment in the mining industries in Africa, but also potential means for other investment related decision making.

The study is organized as follows. After this introductory section, we briefly review the locational theories and China's OFDI in general and in the mining industries. The third section introduces the data and AHP-supported VIKOR methods. Analysis of the data and discussion of the analysis are presented in the fourth section. The last section summarizes the study.

\section{Theories of Locational Selection}

Selecting an appropriate location for certain production activities originates from the location theory. While von Thünen introduced transportation cost to the location selection of agricultural activities, he created a typical location selection "Thünen Circle" that establishes the correlation between agriculture location selection and transportation cost [26,27]. Weber further developed the "Thünen Circle" in 1909 to apply to industrial location selection [28-30]. Following similar logic, cost minimization becomes the primary determinant for finding the best locations for industrial development. In Weber's model, cost is a more complex concept that involves not only transportation cost, but also cost of labor and the effect resulting from agglomeration. In 1960, Hymer proposed the theory of monopoly advantage, which suggests that transnational corporations often select the headquarters and places of investment based on national competitiveness, an even more complex concept, but still rooted in cost-minimization [31]. The concept of location selection for outward foreign direct investment (OFDI) was explicitly discussed in Dunning's eclectic paradigm, which was also referred to as the OLI model, namely, Ownership, Location and Internationalization [32]. In this paradigm, locational advantage is formally discussed as one of the determinants for considering OFDI. Buckley and Casson [33] regard the internalization of the external market as a process of location selection, with the goal still being cost minimization. Investment will always flow to locations where the overall cost is the least among the competitors, though the definition of "cost" becomes even more complex, involving many dimensions beyond the original transportation cost as in von Thünen's model, or cost of production factors as in later theories [16]. 
Newer studies often follow similar trains of thought when analyzing various determinants of location selection for OFDI. Recent advancements in multi-criteria decisionmaking analytical approaches provide more tools for further understanding of the complex decision-making processes for OFDI. For instance, Ding and Sun [34] analyzed the spatial distribution of China's OFDI globally and concluded that the current spatial pattern was a direct result of constant changes in the spatial flow of investment increments brought by China's Belt and Road Initiative (BRI) instead of a reallocation of China's OFDI. Huang and Chen [35] analyze the evolution and development trajectory of China's OFDI in the United States from 2000 to 2014 using the geographical concentration index and concludes that China's OFDI in the United States has a clear spatial clustering pattern in which most investment went to locations where comprehensive competitiveness is high. In their analysis of China's investment to the state of Indiana, Kelley, Coner and Lyles [36] suggest that the presence of overseas Chinese nationals also plays a significant role in China's overall OFDI, on some occasions even more important roles than local tax rate, income level and rent level. These studies draw coherent conclusion that the broadly defined "cost minimization" is still the determining factor for the locational choice of investment.

Studies that specifically focus on OFDI in the mining industries are very limited despite the obvious importance of such investment. Yet as China develops gradually as an industrialized nation, the demands for raw or refined minerals has become an inseparable part of China's continued industrialization [22]. Such demands have started to attract governmental and scholarly attention. Per our meta-analysis, currently, most of China's OFDI studies focus primarily on three aspects. The first focuses on establishing a relatively full set of evaluation systems that attempt to evaluate potential gains for China's OFDI. For instance, Wang [37] evaluated the investment environment of the countries along the Belt and Road Initiative for their coal resources and constructed a set of evaluation standards for China's OFDI in coal mining industries along the Belt and Road. The second focuses on ranking locations along the BRI regions for their appropriateness for OFDI. Wu [38] and Jiang [39] used factor analysis to evaluate a series of factors involving cost, investment environment and other relevant factors to rank central Asian nations for China's OFDI. The factor analysis did incorporate multiple criteria (factors), but the ranking was not based on compromised importance among those factors, which makes the ranking less convincing. The third is the study of determinants of location selection. Liu [40] studied how energy companies select locations for investment taking into consideration institutional, economic development, and social factors of 74 countries. In addition, Xue, Zhang and Zou [41] analyzed the 2000-2014 panel OFDI data of China's state-owned mining enterprises and found that investment tends to go to countries or regions with higher entrance costs but lower supervision restrictions. Most of these studies, however, often pay less attention to the integrated, multiple criteria supported decision-making process. Factors are often considered as equally important when evaluating the appropriateness or ranking for China's OFDI. In addition, most of these studies focus primarily on the traditional resourcerich regions in central Asia, the Middle East, and southeast Asia. Studies on African countries often focus on specific mineral resources' location selection. An overall location selection strategy for various mineral resources in African countries is still absent. The current study attempts to fill in this gap.

\section{Data and Method}

\subsection{Data}

This study has collected mining investment data from Standard and Poor's Global Market Intelligence (https://www.spglobal.com/marketintelligence/en/)'s metal and mining database. The database is one of the most comprehensive that associate projects with investors, investing countries and detailed mineral resources. Based on the database, China has in total 123 mining investment projects in Africa in 25 strategic locations where mineral resources are abundant. 
The relative stable geological condition of the African continent makes it one of the most mineral-rich locations on Earth. African countries have long been regarded as resource-rich sources that support industrialization in the world [42]. Although it is tempting to use all countries or regions in Africa in the current study, considering data availability for building evaluating indicators, we must limit the number of countries that can be evaluated in our current study framework.

When selecting individual countries, this study considers the following five criteria. First, the countries selected shall be representative of the broad spectrum of African countries that are mutually complementary in industrial structures so that all possible scenarios will be considered. Based on Chenery and Syrquin [43], countries can be generally categorized into three stages of development according to the typical shifts in the sources of growth, namely, the stages of primary production, industrialization and, finally, the developed stage. The production in countries at the primary production stage is dominated by agriculture with limited demand for manufactured goods. The production of industrialization countries shifts to resource mining and refinery and manufacturing. For the developed economies, it is the rise of service industries that mark this stage. Although African countries have experienced impressive growth in the new century thanks primarily to stable and plentiful mineral and oil reserves, except for a very few, the majority of African countries are in the primary production and early stages of industrialization [19]. Our selection of countries will focus primarily on countries in the primary and early industrialization stages because countries in these two stages could potentially benefit the most from accepting China's OFDI in the mining industries. Second, according to the project data of the S.P. Global Financial Intelligence database and the analysis of China's spatiotemporal investment patterns in Africa, the location of global investment there is primarily in the Sub-Sahara, as are China's existing investment projects. Hence our current study selects countries in Sub-Sharan Africa. Third, to better evaluate investment priorities for different candidates, this study considers not only countries that China has invested in, but also countries China intends to invest in soon. Fourth, the countries that are selected for analysis not only have abundance in mineral resources, but also have a relatively large variety of mineral resources. Fifth, because the evaluation will cover a broad spectrum of conditions including political, socioeconomic, and geological aspects, data availability is essential for successful evaluation. Countries selected shall have available data that we can either extract or calculate from to obtain necessary evaluation metrics.

Based on these considerations, we have identified six countries for our evaluation. These include Djibouti, Malawi, Ghana, Uganda, Tanzania, and Eritrea (marked as $\mathrm{A}_{1}-\mathrm{A}_{6}$ in Table 1). Of the six countries, based on their per-capita GDP in 2019 and the Sub-Saharan Africa section of the International Monetary Fund's Regional Economic Outlook, Malawi (\$399) is the example of a primary production economy. Uganda (\$686) and Tanzania (\$1052) are in the early stages of industrialization. Eritrea (\$2207), Ghana (\$2244), and Djibouti (\$2457) can be regarded as countries in the middle stages of industrialization. No late industrialization or developed stage countries were selected because these countries have relatively lower interest in China's OFDI in the mining industries as their primary economic drive is in the service industries and so are not among the high priority groups for China's OFDI in mining industries. Among these six countries, China has already invested in the mining industries of Eritrea, Ghana, and Tanzania, but also aims to invest in Malawi, Uganda, and Djibouti in the future. These six countries are rich in mineral resources and have a relatively large variety of mineral resources, each with distinctively dominant mineral resource (see Table 1) and are of strategic importance to support China's ongoing industrialization. 
Table 1. Mineral resources of the six selected countries.

\begin{tabular}{|c|c|c|}
\hline Country & Mineral Resources & Additional Information \\
\hline Djibouti $\left(\mathrm{A}_{1}\right)$ & Salt, Limestone, Perlite, etc. & Perlite: 48 million tons \\
\hline Malawi $\left(\mathrm{A}_{2}\right)$ & $\begin{array}{l}\text { Rare Earths, Titanium, Bauxite, } \\
\text { Uranium, Diamond, Pyrite, } \\
\text { Limestone, Coal, Graphite, etc. }\end{array}$ & $\begin{array}{l}\text { Titanium: approximately } 1.5 \text { billion tons } \\
\text { Bauxite: } 280 \text { million tons } \\
\text { Uranium: } 2.4 \text { million tons }\end{array}$ \\
\hline Ghana $\left(\mathrm{A}_{3}\right)$ & $\begin{array}{l}\text { Gold, Diamond, Bauxite, Iron, } \\
\text { Manganese, Oil and Gas, etc. }\end{array}$ & $\begin{array}{l}\text { Gold: } 200 \text { million ounces } \\
\text { Bauxite: } 18.91 \text { million tons } \\
\text { Manganese } 49 \text { million tons }\end{array}$ \\
\hline Uganda $\left(\mathrm{A}_{4}\right)$ & $\begin{array}{l}\text { Oil, Mica, Feldspar, Limestone, } \\
\text { Phosphate, Iron, Tantalum, } \\
\text { Vanadium, Copper, Cobalt, } \\
\text { Molybdenum, Graphite, and } \\
\text { Gold, etc. }\end{array}$ & $\begin{array}{l}\text { Oil: } 6 \text { billion barrels } \\
\text { Natural gas: } 14.2 \text { billion cubic meters } \\
\text { Phosphate: } 250 \text { million tons }\end{array}$ \\
\hline Tanzania $\left(\mathrm{A}_{5}\right)$ & $\begin{array}{l}\text { Gold, Diamond, Iron, Nickel, } \\
\text { Uranium, Phosphate, Coal, } \\
\text { Natural Gas, etc. }\end{array}$ & $\begin{array}{l}\text { Gold: } 18 \text { million ounces } \\
\text { Diamond: } 2.5 \text { million tons } \\
\text { Iron: } 130 \text { million tons }\end{array}$ \\
\hline Eritrea $\left(\mathrm{A}_{6}\right)$ & $\begin{array}{l}\text { Copper, Zinc, Gold, Silver, Lead, } \\
\text { Iron, Manganese, Nickel, Barite, } \\
\text { Kaolin, Asbestos, Feldspar, etc. }\end{array}$ & \\
\hline
\end{tabular}

\subsection{Methods: A Multi-Criteria Decision-Making (MCDM) Approach, the VIKOR Method}

The VIKOR method is an MCDM approach proposed by Opricovic and named in Serbian (VIseKriterijumska Optimizacija I Kompromisno Resenje). The approach has been further detailed in two publications in the European Journal of Operational Research by Opricovic and Tzeng [44] and Opricovic and Tzeng [45]. The central idea of the VIKOR method is essentially an evaluation of an object's "distance" to the favorable criteria. It was originally developed to solve decision-making problems with conflicting solutions and criteria with different units. VIKOR assumes that compromise is necessary and acceptable for conflicting solutions because the criteria for evaluating a specific decision often come in various forms with different units and measure different aspects that are often incommensurable. Compromise suggests that the decision maker will seek a solution that is closest to the ideal, and the alternatives are evaluated according to all established criteria. The VIKOR ranks alternatives and determines the best compromise among the choices. Considering China's investment decisions in African countries will ultimately involve aspects of resource abundance, local institutional conditions, political conditions, infrastructure completeness, international market, and other costs, The VIKOR method provides a rather effective evaluation approach to produce a reasonable solution.

In essence, the VIKOR approach attempts to find a solution that minimizes the "distance" to the ideal value. The evaluation follows these steps:

First, a group of evaluation criteria will be collected for each investment candidate country, recorded as $\boldsymbol{F}=\left\{f_{i j}\right\}, i=1, \ldots$, where $n$ is the number of criteria, $j=1, \ldots, m$, is the number of candidates under consideration. For evaluation convenience, the individual $f_{\neg i j}$ is often standardized as the fraction of the maximum value of each row (each criterion).

Second, the favorable value and the less favorable value of a criterion is determined as $f_{i}^{*}$ and $f_{i}$. For the benefit criterion, $f_{i}^{*}$ is the maximum value of all the collected information; and for cost criterion, $f_{i}^{*}$ is the minimum value.

Third, the group effectiveness value is determined for any solution as a weighted and normalized Manhattan distance (we tried other distance measures such as the Euclidean distance in determining the group effectiveness value, and the results stay unchanged):

$$
S_{j}=\sum_{i=1}^{n} w_{i}\left(f_{i}^{*}-f_{i j}\right) /\left(f_{i}^{*}-\hat{f_{i}}\right)
$$

and the individual regretful-ness value as a Chebyshev distance: 


$$
R_{j}=\max \left(w_{i}\left(f_{i}^{*}-f_{i j}\right) /\left(f_{i}^{*}-\hat{f_{i}}\right)\right)
$$

where $w_{i}$ is the weight assigned to individual criterion. The weights are determined in this study through an expert survey and conversion system, namely, the analytical hierarchical process (AHP) method. Experts' opinions are collected through an intensive questionnaire survey during our initial research period. A group of professors, governmental officials, and mining industry practitioners are surveyed to evaluate the importance of the selected criteria in terms of investing in mining industries in African countries. The feedback is processed to obtain the weights. Detailed procedures will be presented in a later section.

Fourth, a benefit ratio $Q_{j}$ for the $j$ th region can be obtained as:

$$
Q_{j}=v\left(S_{j}-S^{*}\right) /\left(S^{-}-S^{*}\right)+(1-v)\left(R_{j}-R^{*}\right) /\left(R^{-}-R^{*}\right)
$$

where $S^{*}=\min \left(S_{j}\right), S^{-}=\max \left(S_{j}\right), R^{*}=\min \left(R_{j}\right)$, and $R^{-}=\max \left(R_{j}\right) . v$ is regarded as a weight for the strategy of maximum group utility, whereas $(1-v)$ is the weight of the individual regret. Often $v$ is set to be 0.5 , and this is the case in the current study to reflect that the benefits and regrets are similarly weighted, since we do not have a strong reason to favor one over the other. The compromise is in the middle point. After such a process, the group utility can be maximized while the negative impact minimized.

Fifth, a solution is obtained via ranking the $S_{j}, R_{j}$, and $Q_{j}$ values ascendingly. A compromised solution is obtained by the best ranked $Q_{j}$ (minimum $Q_{j\urcorner}$ ) if two conditions are satisfied.

Condition 1: $Q_{\neg j}-Q_{(j+1)} \geq 1 /(m-1)$, where $Q_{(j+1)}$ is the second ranked in $Q$.

Condition 2: $S_{j}$ and/or $R_{j}$ must also be the best ranked (minimum).

Condition 1 is regarded as "acceptable advantage," while condition 2 is regarded as "acceptable stability in decision making." This is because when both conditions are met, this compromised solution is stable within a decision-making process. If, however, one of the conditions is not satisfied, then a set of compromised solutions will be proposed that consists of $j$ and $(j+1)$ if only the second condition is not satisfied, or $j, j+1, \ldots, j+k$ if the first condition is not satisfied. $k$ is determined by the relation $Q_{(j+k)}-Q_{j\urcorner}<1 /(m-1)$, and $j+k \leq m$.

The obtained compromised solution may be accepted by the decision makers because it provides a maximum utility of the majority (represented by $\min (S)$ ), and a minimum individual regret of the opponent (represented by $\min (R)$ ). In this process, the measures $S$ and $R$ are integrated into $Q$ to obtain this compromised solution, which forms the basis for an agreement established by mutual concessions.

\subsection{The Evaluation Indicators}

To proceed with the VIKOR decision-making process, a relatively complete set of evaluating indicators must be determined a priori. This set of evaluating indicators is recorded as $\boldsymbol{F}=\left\{f_{i j}\right\}$, as aforementioned.

Selection of specific indicators follows typical location theory narratives. In the classical location theories, cost minimization is the ultimate goal that determines the final location selection of industries [30]. Similar logic applies to investment location selection, though detailed manifestation varies per different industries, cost (broadly defined) minimization and benefit maximization are still the goals for optimal locations. Dunning [32] and Dunning [46] discussed the location factors for OFDI in detail. Based on the eclectic paradigm, Dunning considered four types of factors that determine the OFDI's location, namely, market factors, including market size, market growth, market patterns and customer types; trade barriers, including tariff and the cost of localization of foreign investment; regional costs, including costs for raw materials, labor, and transportation; and the investment environment, including the degree of preference of policies and regulations relating to foreign investment, the stability of foreign direct investment policies and the stability of financial currencies. These four types of factors provide the foundation for building the evaluating indicators for the current study. 
When selecting individual indicators, our goal is to provide an evaluating tool that best reflects the investment host countries' broad investment environment, especially investment environment in the mining industries. Based on the classical location theory, previous studies in foreign mining industry investment [47-51], the unique characteristics of the mining industry, and data availability for the six candidate countries, this study selects 23 individual indicators categorized into 6 groups, namely, the political and developmental environment, economic development, legal environment, resource endowment and value, geological conditions, and local infrastructure (Table 2).

Table 2. Indicators and how they are measured.

\begin{tabular}{|c|c|c|}
\hline Criteria & Individual Indicators (B) & Values \\
\hline \multirow{4}{*}{$\begin{array}{l}\text { Political } \\
\text { environment } \\
\quad(0.531)\end{array}$} & Political system B1 & $\begin{array}{l}1=\text { Not democratic; } 2=\text { weakly democratic; } 3=\text { somewhat } \\
\text { democratic; } 4=\text { relatively democratic; } 5=\text { democratic }\end{array}$ \\
\hline & Foreign relationship B2 & $\begin{array}{c}1=\text { Has embassy with China; } 2=\text { Relatively friendly with China; } \\
3=\text { Partnership with China; } 4=\text { Traditionally partnership with } \\
\text { China; } 5 \text { = Ally-like relationship with China }\end{array}$ \\
\hline & $\begin{array}{l}\text { Participation in international } \\
\text { organizations B3 }\end{array}$ & $\begin{array}{c}1=\text { No participation; } 2 \text { = participate in } 1-2 \text { organizations; } \\
3=\text { participate in } 3-5 \text { organizations; } 4=\text { participate in } 6-10 \\
\text { organizations; } 5=\text { participate in more than } 10 \text { organizations }\end{array}$ \\
\hline & MOU B4 & $\begin{array}{l}1=\text { No MOU or MOU is negotiating with China; } 2=\text { Has MOU } \\
\text { with China in other fields; } 3=\text { Has MOU at the mining industry } \\
\text { level; } 4=\text { Has MOU at the departmental level; } 5=\text { Has MOU at } \\
\text { the national level }\end{array}$ \\
\hline \multirow{3}{*}{$\begin{array}{l}\text { Economic } \\
\text { environment } \\
(0.103)\end{array}$} & GDP B5 & $\begin{array}{c}\text { Based on } 2019 \text { GDP ranking in Africa: } \\
1=\text { ranked } 41-54 ; 2=\text { ranked } 31-40 ; 3=\text { ranked } 21-30 \\
4=\text { ranked } 11-20 ; 5=\text { ranked top } 10\end{array}$ \\
\hline & Industrial structure B6 & $\begin{array}{l}\text { Based on the industrialization level of the six countries: } \\
1=\text { ranked } 5 \text { th and } 6 \text { th; } 2=\text { ranked } 4 \text { th; } 3=\text { ranked } 3 \mathrm{rd} ; \\
\qquad 4=\text { ranked second; } 5=\text { ranked first. }\end{array}$ \\
\hline & Development of mining industry B7 & $\begin{array}{l}\text { Based on the portion of mining industry in all industries of the } \\
\text { six countries: } 1=\text { ranked } 5 \text { th and } 6 \text { th; } 2 \text { = ranked } 4 \text { th; } \\
3=\text { ranked } 3 \text { rd; } 4=\text { ranked second; } 5=\text { ranked first. }\end{array}$ \\
\hline \multirow{4}{*}{$\begin{array}{l}\text { Legal environment } \\
\qquad(0.044)\end{array}$} & Investment protection regulation $\mathrm{B} 8$ & $\begin{array}{c}1=\text { No regulation; } 2=\text { little regulation; } 3=\text { some regulation; } \\
4=\text { has regulation; } 5=\text { many types of regulation. }\end{array}$ \\
\hline & Mining regulation B9 & $\begin{array}{c}1=\text { No regulation; } 2=\text { little regulation; } 3=\text { some regulation; } \\
4=\text { has regulation; } 5=\text { many types of regulation. }\end{array}$ \\
\hline & Environmental protection regulation B10 & $\begin{array}{c}1=\text { No regulation; } 2=\text { little regulation; } 3=\text { some regulation; } \\
\quad 4=\text { has regulation; } 5=\text { many types of regulation. }\end{array}$ \\
\hline & FDI regulation B11 & $\begin{array}{c}1=\text { No regulation; } 2=\text { little regulation; } 3=\text { some regulation; } \\
\quad 4=\text { has regulation; } 5=\text { many types of regulation. }\end{array}$ \\
\hline \multirow{3}{*}{$\begin{array}{l}\text { Resource } \\
\text { endowment and } \\
\text { value }(0.171)\end{array}$} & Types of minerals and demand B12 & $\begin{array}{c}1 \text { = Very low demand; } 2=\text { Low demand } 3=\text { Some demand; } \\
4=\text { High demand } ; 5=\text { Very high demand. }\end{array}$ \\
\hline & Mineral reserves and quality B13 & $\begin{array}{c}1=\text { small reserves and low quality; } 2=\text { medium low reserves } \\
\text { and quality; } 3=\text { medium reserves and quality; } 4=\text { relatively } \\
\text { large reserves and quality; } 5=\text { large reserves and quality }\end{array}$ \\
\hline & Socioeconomic values B14 & $\begin{array}{l}\text { Based on the ranking of the six countries: } 1=\text { ranked } 5 \text { th and } \\
6 \text { th; } 2=\text { ranked } 4 \text { th; } 3=\text { ranked } 3 \text { rd; } 4=\text { ranked second; } \\
5=\text { ranked first. }\end{array}$ \\
\hline \multirow{2}{*}{$\begin{array}{l}\text { Geological } \\
\text { conditions and } \\
\text { relevant work } \\
(0.068)\end{array}$} & Survey completeness B15 & $\begin{array}{l}1=\text { No survey } ; 2=\text { Limited survey; } 3 \text { = Some survey; } \\
4=\text { Relatively complete survey; } 5 \text { = Complete survey. }\end{array}$ \\
\hline & Credibility of local information B16 & $\begin{array}{l}\text { Based on the ranking of the six countries: } 1=\text { ranked } 5 \text { th } \\
\text { and } 6 \text { th; } 2=\text { ranked } 4 \text { th; } 3=\text { ranked } 3 \mathrm{rd} ; 4=\text { ranked second; } \\
5=\text { ranked first. }\end{array}$ \\
\hline
\end{tabular}


Table 2. Cont.

\begin{tabular}{|c|c|c|}
\hline Criteria & Individual Indicators (B) & Values \\
\hline \multirow{7}{*}{$\begin{array}{l}\text { Infrastructure } \\
\quad(0.083)\end{array}$} & Total length of local road network B17 & $\begin{array}{l}\text { Based on the ranking of the six countries: } 1=\text { ranked } 5 \text { th and } \\
6 \text { th; } 2=\text { ranked } 4 \text { th; } 3=\text { ranked } 3 \text { rd; } 4=\text { ranked second; } \\
\qquad 5=\text { ranked first. }\end{array}$ \\
\hline & Total length of local railway B18 & $\begin{array}{l}\text { Based on the ranking of the six countries: } 1=\text { ranked } 5 \text { th and } \\
6 \text { th; } 2=\text { ranked } 4 \text { th; } 3=\text { ranked } 3 \text { rd; } 4=\text { ranked second; } \\
\qquad 5=\text { ranked first. }\end{array}$ \\
\hline & Local air transportation B19 & $\begin{array}{l}\text { Based on the ranking of the six countries: } 1=\text { ranked } 5 \text { th and } \\
6 \text { th; } 2=\text { ranked } 4 \text { th; } 3=\text { ranked } 3 \mathrm{rd} ; 4=\text { ranked second; } \\
5=\text { ranked first. }\end{array}$ \\
\hline & Local water transportation B20 & $\begin{array}{l}\text { Based on the ranking of the six countries: } 1=\text { ranked } 5 \text { th and } \\
6 \text { th; } 2=\text { ranked } 4 \text { th; } 3=\text { ranked } 3 \text { rd; } 4=\text { ranked second; } \\
\qquad 5=\text { ranked first. }\end{array}$ \\
\hline & Hydropower B21 & $\begin{array}{l}\text { Based on the ranking of the six countries: } 1=\text { ranked } 5 \text { th and } \\
6 \text { th; } 2=\text { ranked } 4 \text { th; } 3=\text { ranked } 3 \text { rd; } 4=\text { ranked second; } \\
\qquad 5=\text { ranked first. }\end{array}$ \\
\hline & Electricity B22 & $\begin{array}{l}\text { Based on the ranking of the six countries: } 1=\text { ranked } 5 \text { th and } \\
6 \text { th; } 2=\text { ranked } 4 \text { th; } 3=\text { ranked } 3 \text { rd; } 4=\text { ranked second; } \\
\qquad 5=\text { ranked first. }\end{array}$ \\
\hline & Telecommunication B23 & $\begin{array}{l}\text { Based on the ranking of the six countries: } 1=\text { ranked } 5 \text { th and } \\
6 \text { th; } 2=\text { ranked } 4 \text { th; } 3=\text { ranked } 3 \text { rd; } 4=\text { ranked second; } \\
\qquad 5=\text { ranked first. }\end{array}$ \\
\hline
\end{tabular}

The political and developmental aspect of the host country includes the political system, foreign relationship, participation in international organizations, and the signing of MOUs with China. Among them, political system is measured with the degrees of democracy of the host country. If the government was established without democratic election and changed within a year, it is regarded as "not democratic". If the government was established without democratic election but stayed stable over a year, it is regarded as "weakly democratic". If the government was established with democratic election but changed within a year, it is regarded as "somewhat democratic". If a government was established with democratic election and stayed stable for 1-3 years, it is regarded as "relatively democratic". If the government was established with democratic election and stayed stable for over 3 years, then it is regarded as "democratic". Detailed definitions for the other three indicators are summarized in Table 2. These indicators provide a broad definition of the global geopolitical evaluation of the host countries and their relationship with China. Apparently, investing in a country that might have hostile feelings toward China or Chinese investment in the past will not be beneficial in the long run.

The economic development aspect includes the total economic output, economic structures, and the developing status of the mining industries in the host country. Detailed definitions are also summarized in Table 2. This category describes the potential of the host countries to accept OFDI from China to create a mutually beneficial cooperation in the mining industries.

The local legal environment, specifically the law and regulation conditions regarding investment and mining, includes investment protection regulation, mining regulation, environmental protection regulation, and FDI regulation. The local legal environment serves as both a protection of China's OFDI and in some cases a restriction to protect the local environment and hence place a limit on intensive OFDI in environmentally damaging industries such as mining. If there is no regulation of the corresponding legal environment, it will be assigned value 1 (no regulation). If the country has 1 regulation item, it will be assigned value 2 (little regulation). If the country has $2-3$ regulation items, it will be assigned value 3 (some regulation). If the country has $3-5$ regulation items, it will be 
assigned value 4 (has regulation). If the country has over 5 regulation items, it will be assigned value 5 (many types of regulation) (Table 2).

The category of mineral resources endowment conditions in the host countries is apparently one of the major determining factors for mining industry investment. Types of minerals and demand, mineral reserves and quality, and these minerals' socioeconomic values are considered in this category. Values for "types of minerals and demand" and "mineral's socioeconomic values" are determined based on China's demand and evaluation for the minerals and are acquired through the survey with China's governmental officials, scholars, and mining industry practitioners. "Mineral reserves and quality" information is extracted from the corresponding countries' mineral reserve and quality surveys.

The geological condition category includes primarily the surveys done by China (having no survey is assigned the value of 1 ; having one survey is assigned the value of 2; having 2-3 surveys is assigned the value of 3; having $4-5$ surveys is assigned the value of 4; and having more than 5 surveys is assigned the value of 5), and surveys available from the host countries (this indicator is based on the same survey as China's governmental officials, scholars and mining industry practitioners). This category provides a confidence measure of China's OFDI to the host countries' mining industries.

The infrastructure category includes road length, railroad length, airport capacity, water transportation capacity, hydropower, electricity, and telecommunication capacity. Infrastructure is the fundamental guarantee for profitable OFDI. All values are assigned based on the ranking of the corresponding countries using publicly available data from the Ministry of Commerce of China (http:/ / fec.mofcom.gov.cn/article/gbdqzn/).

These indicators serve the purpose on the national level of suggesting how well an OFDI host country is prepared to engage in global investment and economic activities. All indicators are listed in Table 2. The value of each indicator is ranked based on the specific indicator's meaning and is also summarized in Table 2.

Following these fundamental theoretical narratives and the significant differences in geographical environments, geological characteristics and investment environment characteristics of African countries, this study believes that the selection of mining investment location in Africa is a multi-factor interaction process with conflicting priorities among the indicators and that, as such, compromises will be needed. Before we engage in applying multi-factor decision making via the VIKOR approach, we also need to emphasize that these categories and individual indicators are unlikely to weigh the same when the decision as to whether to invest in a specific country is made. Far from it, we believe for the best understanding of the multifactor decision-making process, it is necessary to weigh those individual indicators and categories based on the opinions of various interested stakeholders, including experts, decision-makers, and practitioners in the mining industry and governmental management departments.

\subsection{AHP Weighting Scheme}

Weighting can happen with both objective ranking, which can be derived from the numeric values of the indicators via statistical means, such as variance explained, entropy calculated, or likelihood ratio compared [52-54], and subjective ranking that relies on prior experience and knowledge of the specific field [55,56]. In decision making, oftentimes weighting is less likely directly derivable from data alone. More importantly, because decision making is not likely a static, one-size-fits-all process, it often requires flexible adjustment because of potential dynamic changes. In such scenarios, experts and practitioners' prior experience and opinions become critical factors for appropriate decisions.

Through a literature review and our previous investigations, we found that the timetested approach, an analytic hierarchy process (AHP), is well suited for providing reasonable weights based on expert opinions for individual indicators in our study to facilitate decision making [55-57]. AHP is proposed to solve operational optimization problems that attempt to integrate various experts' opinions. It is well suited for weighting problems when the goal is layered with sub-categories and individual indicators such as the case in 
our current study. In principle, AHP solves a weighting problem by simulating the thinking process when human beings are faced with a complex decision-making issue. It sets a goal, then finds sub-goals that are components of the goal, then moves further until quantifiable and measurable indicators are identified. Cross-comparison of these individual indicators in terms of their relative importance to their immediate upper-level category will produce quantifiable weights. By repeating this process, we are able to produce a systematic set of weights that incorporate multiple experts' prior experience in the final weighting scheme.

AHP produces weights following these four steps. First, it identifies and establishes the hierarchical structure of the decision-making problem. Second, at each hierarchy (level), it requires establishing a cross-comparison matrix based on surveyed experts' opinions and prior experiences. Third, we will then derive individual weights under each sub-category from the cross-comparison matrix. Fourth, from the bottom up, for each hierarchy (level), a cross-comparison matrix can be established based on the bottom-most layer's weights, and sub-hierarchy (level) weights can be established similarly until all hierarchies obtain their weights [55]. The procedure is nicely implemented in the software YAAHP [58] that the current study uses.

\section{Results and Discussion}

To apply the AHP expert evaluating approach to provide weights for the different indicators, and also to solicit experts' opinions on how to set values for some individual indicators based on the rules listed in Table 2, a survey with pairwise cross-evaluation of the 23 indicators under the 6 groups (the structure of the indicators is reported in Table 2) is distributed through email and individual interviews to a group of 300 interested stakeholders of mining investment, including governmental officials, academic scholars, and mining industry investment practitioners. The experts were asked to cross-compare individual indicators based on a scale of 1-9 in the cross-comparison matrix under each sub-category, where 1 suggests both indicators are similarly important under the subcategory, 3 means the row indicator is slightly more important than the column indicator, and 5 means more important, 7 even more important, and 9 dominant. Even numbers are used if experts' opinions conflict. In addition, during the survey, the experts were also asked to provide their values based on their prior experiences for individual indicators based on Table 2's definition to compensate for possible incompleteness of the indicators in some countries. Table 2 gives the explanations of how to rank each indicator. The experts were asked to provide their assessment of those indicators for each of the six countries based on these explanations. An amount of 246 survey reports were collected. Among them, 210 contained useful and complete information. Since the individual indicators were recorded as ranking orders, the median scores for each individual indicator under the six categories are reported in Table 3 . The standardized values are reported in Table 4 along with the favorable $\left(f_{i}^{*}\right)$ and least favorable $\left(f_{i}^{\wedge}\right)$ values. By manipulating the pairwise cross-evaluation survey results and the AHP structure, using the YAAHP software [58], we are able to produce the individual weight for each indicator under the goal of selecting the optimal location for OFDI in mining industries. The results are reported in Table 5.

Table 3. Expert evaluation scores.

\begin{tabular}{|c|c|c|c|c|c|c|}
\hline Indicators & $\mathbf{A}_{1}$ & $\mathbf{A}_{2}$ & $\mathbf{A}_{3}$ & $\mathbf{A}_{4}$ & $\mathbf{A}_{5}$ & $\mathbf{A}_{6}$ \\
\hline $\mathbf{B}_{1}$ & 5 & 3 & 5 & 5 & 5 & 5 \\
\hline $\mathbf{B}_{2}$ & 1 & 1 & 4 & 4 & 4 & 1 \\
\hline $\mathbf{B}_{3}$ & 2 & 2 & 3 & 3 & 3 & 3 \\
\hline $\mathbf{B}_{4}$ & 2 & 2 & 4 & 2 & 4 & 4 \\
\hline $\mathbf{B}_{5}$ & 1 & 2 & 5 & 4 & 5 & 2 \\
\hline $\mathbf{B}_{6}$ & 1 & 1 & 2 & 3 & 2 & 4 \\
\hline
\end{tabular}


Table 3. Cont.

\begin{tabular}{|c|c|c|c|c|c|c|}
\hline Indicators & $\mathbf{A}_{1}$ & $\mathbf{A}_{2}$ & $\mathbf{A}_{3}$ & $\mathbf{A}_{4}$ & $\mathbf{A}_{5}$ & $\mathbf{A}_{6}$ \\
\hline $\mathbf{B}_{7}$ & 2 & 4 & 4 & 3 & 4 & 2 \\
\hline $\mathbf{B}_{8}$ & 1 & 1 & 2 & 3 & 4 & 1 \\
\hline B9 $_{9}$ & 2 & 2 & 5 & 4 & 5 & 5 \\
\hline$B_{10}$ & 2 & 3 & 4 & 5 & 5 & 2 \\
\hline $\mathbf{B}_{11}$ & 3 & 3 & 3 & 5 & 5 & 3 \\
\hline $\mathbf{B}_{12}$ & 1 & 3 & 5 & 5 & 5 & 5 \\
\hline $\mathbf{B}_{13}$ & 5 & 5 & 5 & 5 & 5 & 5 \\
\hline $\mathrm{B}_{14}$ & 1 & 1 & 4 & 3 & 5 & 2 \\
\hline $\mathbf{B}_{15}$ & 2 & 2 & 3 & 3 & 5 & 3 \\
\hline $\mathbf{B}_{16}$ & 1 & 1 & 5 & 2 & 3 & 4 \\
\hline $\mathbf{B}_{17}$ & 1 & 2 & 3 & 4 & 5 & 1 \\
\hline $\mathbf{B}_{18}$ & 2 & 1 & 3 & 4 & 5 & 1 \\
\hline $\mathbf{B}_{19}$ & 2 & 1 & 5 & 4 & 3 & 1 \\
\hline $\mathbf{B}_{20}$ & 3 & 1 & 4 & 1 & 5 & 2 \\
\hline $\mathbf{B}_{21}$ & 1 & 1 & 2 & 3 & 5 & 4 \\
\hline$B_{22}$ & 1 & 1 & 4 & 3 & 5 & 2 \\
\hline $\mathbf{B}_{23}$ & 1 & 2 & 4 & 3 & 5 & 1 \\
\hline
\end{tabular}

Table 4. Standardized values and the ideal and least ideal values.

\begin{tabular}{ccccccccc}
\hline Indicators & $\mathbf{A}_{\mathbf{1}}$ & $\mathbf{A}_{\mathbf{2}}$ & $\mathbf{A}_{\mathbf{3}}$ & $\mathbf{A}_{\mathbf{4}}$ & $\mathbf{A}_{\mathbf{5}}$ & $\mathbf{A}_{\mathbf{6}}$ & $f_{i}^{*}$ & $f_{i}$ \\
\hline $\mathbf{B}_{\mathbf{1}}$ & 1.00 & 0.60 & 1.00 & 1.00 & 1.00 & 1.00 & 1.00 & 0.60 \\
\hline $\mathbf{B}_{\mathbf{2}}$ & 0.25 & 0.25 & 1.00 & 1.00 & 1.00 & 0.25 & 1.00 & 0.25 \\
\hline $\mathbf{B}_{\mathbf{3}}$ & 0.67 & 0.67 & 1.00 & 1.00 & 1.00 & 1.00 & 1.00 & 0.67 \\
\hline $\mathbf{B}_{\mathbf{4}}$ & 0.50 & 0.50 & 1.00 & 0.50 & 1.00 & 1.00 & 1.00 & 0.50 \\
\hline $\mathbf{B}_{\mathbf{5}}$ & 0.20 & 0.40 & 1.00 & 0.80 & 1.00 & 0.40 & 1.00 & 0.20 \\
\hline $\mathbf{B}_{\mathbf{6}}$ & 0.25 & 0.25 & 0.50 & 0.75 & 0.50 & 1.00 & 1.00 & 0.25 \\
\hline $\mathbf{B}_{\mathbf{7}}$ & 0.50 & 1.00 & 1.00 & 0.75 & 1.00 & 0.50 & 1.00 & 0.50 \\
\hline $\mathbf{B}_{\mathbf{8}}$ & 0.25 & 0.25 & 0.50 & 0.75 & 1.00 & 0.25 & 1.00 & 0.25 \\
\hline $\mathbf{B}_{\mathbf{9}}$ & 0.40 & 0.40 & 1.00 & 0.80 & 1.00 & 1.00 & 1.00 & 0.40 \\
\hline $\mathbf{B}_{\mathbf{1 0}}$ & 0.40 & 0.60 & 0.80 & 1.00 & 1.00 & 0.40 & 1.00 & 0.40 \\
\hline $\mathbf{B}_{\mathbf{1 1}}$ & 0.60 & 0.60 & 0.60 & 1.00 & 1.00 & 0.60 & 1.00 & 0.60 \\
\hline $\mathbf{B}_{\mathbf{1 2}}$ & 0.20 & 0.60 & 1.00 & 1.00 & 1.00 & 1.00 & 1.00 & 0.20 \\
\hline $\mathbf{B}_{\mathbf{1 3}}$ & 1.00 & 1.00 & 1.00 & 1.00 & 1.00 & 1.00 & 1.00 & 1.00 \\
\hline $\mathbf{B}_{\mathbf{1 4}}$ & 0.20 & 0.20 & 0.80 & 0.60 & 1.00 & 0.40 & 1.00 & 0.20 \\
\hline $\mathbf{B}_{\mathbf{1 5}}$ & 0.40 & 0.40 & 0.60 & 0.60 & 1.00 & 0.60 & 1.00 & 0.40 \\
\hline $\mathbf{B}_{\mathbf{1 6}}$ & 0.20 & 0.20 & 1.00 & 0.40 & 0.60 & 0.80 & 1.00 & 0.20 \\
\hline $\mathbf{B}_{\mathbf{1 7}}$ & 0.20 & 0.40 & 0.60 & 0.80 & 1.00 & 0.20 & 1.00 & 0.20 \\
\hline $\mathbf{B}_{\mathbf{1 8}}$ & 0.40 & 0.20 & 0.60 & 0.80 & 1.00 & 0.20 & 1.00 & 0.20 \\
\hline $\mathbf{B}_{\mathbf{1 9}}$ & 0.40 & 0.20 & 1.00 & 0.80 & 0.60 & 0.20 & 1.00 & 0.20 \\
\hline $\mathbf{B}_{\mathbf{2 0}}$ & 0.60 & 0.20 & 0.80 & 0.20 & 1.00 & 0.40 & 1.00 & 0.20 \\
\hline & & & & & & & \\
\hline
\end{tabular}


Table 4. Cont.

\begin{tabular}{ccccccccc}
\hline Indicators & $\mathbf{A}_{\mathbf{1}}$ & $\mathbf{A}_{\mathbf{2}}$ & $\mathbf{A}_{\mathbf{3}}$ & $\mathbf{A}_{\mathbf{4}}$ & $\mathbf{A}_{\mathbf{5}}$ & $\mathbf{A}_{\mathbf{6}}$ & $f_{i}{ }^{*}$ & ${f_{i}}^{{ }^{*}}$ \\
\hline $\mathbf{B}_{\mathbf{2 1}}$ & 0.20 & 0.20 & 0.40 & 0.60 & 1.00 & 0.80 & 1.00 & 0.20 \\
\hline $\mathbf{B}_{\mathbf{2 2}}$ & 0.20 & 0.20 & 0.80 & 0.60 & 1.00 & 0.40 & 1.00 & 0.20 \\
\hline $\mathbf{B}_{\mathbf{2 3}}$ & 0.20 & 0.40 & 0.80 & 0.60 & 1.00 & 0.20 & 1.00 & 0.20 \\
\hline
\end{tabular}

Table 5. AHP determined weights of individual indicators.

\begin{tabular}{|c|c|c|c|c|}
\hline Goal & Criteria & Individual Indicators (B) & $\begin{array}{l}\text { Individual Indicators' } \\
\text { Weights on Criteria }\end{array}$ & $\begin{array}{c}\text { Individual Indicators' } \\
\text { Weight on the Goal }\left(W_{i}\right)\end{array}$ \\
\hline \multirow{23}{*}{$\begin{array}{l}\text { OFDI location } \\
\text { selection }\end{array}$} & \multirow{4}{*}{$\begin{array}{l}\text { Political environment } \\
\qquad(0.531)\end{array}$} & Political system $B_{1}$ & 0.210 & 0.1115 \\
\hline & & Foreign relationship $B_{2}$ & 0.195 & 0.1035 \\
\hline & & $\begin{array}{l}\text { Participation in international } \\
\text { organizations } B_{3}\end{array}$ & 0.164 & 0.0871 \\
\hline & & MOU B 4 & 0.432 & 0.2294 \\
\hline & \multirow{3}{*}{$\begin{array}{c}\text { Economic } \\
\text { environment }(0.103)\end{array}$} & GDP $B_{5}$ & 0.260 & 0.0268 \\
\hline & & Industrial structure $\mathrm{B}_{6}$ & 0.327 & 0.0337 \\
\hline & & $\begin{array}{l}\text { Development of mining } \\
\text { industry } B_{7}\end{array}$ & 0.413 & 0.0425 \\
\hline & \multirow{4}{*}{$\begin{array}{l}\text { Legal environment } \\
\qquad(0.044)\end{array}$} & $\begin{array}{l}\text { Investment protection } \\
\text { regulation } \mathrm{B}_{8}\end{array}$ & 0.384 & 0.0169 \\
\hline & & Mining regulation $\mathrm{B}_{9}$ & 0.301 & 0.0132 \\
\hline & & $\begin{array}{l}\text { Environmental protection } \\
\text { regulation } \mathrm{B}_{10}\end{array}$ & 0.123 & 0.0054 \\
\hline & & FDI regulation $B_{11}$ & 0.192 & 0.0084 \\
\hline & \multirow{3}{*}{$\begin{array}{l}\text { Resource endowment } \\
\text { and value }(0.171)\end{array}$} & $\begin{array}{c}\text { Types of minerals and } \\
\text { demand } \mathrm{B}_{12}\end{array}$ & 0.550 & 0.0941 \\
\hline & & $\begin{array}{l}\text { Mineral reserves and } \\
\text { quality } B_{13}\end{array}$ & 0.210 & 0.0359 \\
\hline & & Socioeconomic values $\mathrm{B}_{14}$ & 0.240 & 0.0410 \\
\hline & \multirow{2}{*}{$\begin{array}{l}\text { Geological conditions } \\
\text { and relevant work } \\
\qquad(0.068)\end{array}$} & Survey completeness $B_{15}$ & 0.667 & 0.0454 \\
\hline & & $\begin{array}{l}\text { Credibility of local } \\
\text { information } \mathrm{B}_{16}\end{array}$ & 0.333 & 0.0226 \\
\hline & \multirow{7}{*}{ Infrastructure (0.083) } & $\begin{array}{c}\text { Total length of local road } \\
\text { network } B_{17}\end{array}$ & 0.065 & 0.0054 \\
\hline & & $\begin{array}{l}\text { Total length of local } \\
\text { railway } B_{18}\end{array}$ & 0.224 & 0.0186 \\
\hline & & Local air transportation $\mathrm{B}_{19}$ & 0.051 & 0.0042 \\
\hline & & Local water transportation $\mathrm{B}_{20}$ & 0.146 & 0.0121 \\
\hline & & Hydropower $B_{21}$ & 0.199 & 0.0165 \\
\hline & & Electricity $\mathrm{B}_{22}$ & 0.215 & 0.0178 \\
\hline & & Telecommunication $\mathrm{B}_{23}$ & 0.100 & 0.0083 \\
\hline
\end{tabular}

By feeding data in Tables 4 and 5 into the VIKOR procedure, the resulting $S_{j}, R_{j}$ and $Q_{j}$ for each country and the ranking are recorded in Table 6. 
Table 6. VIKOR results for the six countries.

\begin{tabular}{ccccccc}
\hline Countries & $\mathbf{A}_{\mathbf{1}}$ & $\mathbf{A}_{\mathbf{2}}$ & $\mathbf{A}_{\mathbf{3}}$ & $\mathbf{A}_{\mathbf{4}}$ & $\mathbf{A}_{\mathbf{5}}$ & $\mathbf{A}_{\mathbf{6}}$ \\
\hline$S_{j}$ & 0.8420 & 0.8638 & 0.1184 & 0.3868 & 0.0359 & 0.3265 \\
$R_{j}$ & 0.2294 & 0.2294 & 0.0303 & 0.2294 & 0.0225 & 0.1035 \\
$Q_{j}$ & 0.9868 & 1.0000 & 0.0686 & 0.7119 & 0.0000 & 0.3712 \\
$S_{j}$ ranking & 5 & 6 & 2 & 4 & 1 & 3 \\
$R_{j}$ ranking & 4 & 4 & 2 & 4 & 1 & 3 \\
$Q_{j}$ ranking & 5 & 6 & 2 & 4 & 1 & 3 \\
\hline
\end{tabular}

The results from Table 6 are straightforward. For the six countries that are included in the current study, the VIKOR approach suggests the final ranking for China's OFDI in mining industries is that Tanzania $\left(\mathrm{A}_{5 \neg}\right)$ might be the best choice for investment in the immediate future, followed by Ghana $\left(\mathrm{A}_{3}\right)$, Eritrea $\left(\mathrm{A}_{6}\right)$, Uganda $\left(\mathrm{A}_{4}\right)$, Djibouti $\left(\mathrm{A}_{1}\right)$, and Malawi $\left(A_{2}\right)$. Surprisingly, Eritrea is one of the countries that China had already invested in its mining industries but is ranked less favorably than Tanzania and Ghana for mining OFDI in our study (3rd). Ghana seems to be a viable candidate for the next round of China's investment in mining industries in Africa. The other two countries, Djibouti and Malawi, are less favorable for China's near future OFDI in mining industries. By checking the individual indicators, along with their AHP produced weights, we can draw the following detailed conclusions.

First, based on the experts' opinions, using the semi-quantitative AHP approach, this study discovers from an OFDI perspective that the political environment has the highest weight for interested Chinese stakeholders when determining locations for investment in the mining industry in Africa (0.531, Table 1). This is followed by resource endowment and value (0.171), economic environment (0.103), infrastructure (0.083), geological conditions and relevant work (0.068), and legal environment (0.044). This result agrees with many other studies that investigate investment in Africa, especially China's investment in the mining industries $[25,48,59]$. This is understandable since investment in mining industries tends to be long-term investment, a stable political environment provides higher security for guaranteed investment return. An unstable political environment means that investment risk could easily be out of control. Only for a politically stable country will the high resource endowment and value become an important consideration for investing in mining industries. Economic environment and infrastructure represent the potential for the host countries to develop successful and longer-term investing plans with China. Although the current study investigates China's OFDI in the mining industry in African countries, the mining industry does not exist in a vacuum. It can hardly develop successfully without the support from other industries in the economy and the fundamental infrastructure, such as road, railway, and the like. Geological conditions and survey and the legal environment of the host countries tend to weigh less when the interested stakeholders are making the decision for investment. For one thing, it is well known that the African continent has been in a very stable geological status for millions of years, which suggests global survey through advanced remote sensing technology is sufficient to provide satisfactory results of the geological conditions and resource reserves for any of the host countries. For another, while the local legal environment is important for China's longer-term OFDI, it also reflects the possibility that most of the host countries' legal environments are relatively weak. Many of China's mining companies in African countries are often operating on a semi-autonomous status $[60,61]$, suggesting local legal environment might not present as a significant impact factor for China's OFDI location decisions.

Second, this study suggests that the AHP-supported VIKOR approach provides an important ranking for not only the six candidate countries examined in this study, namely, Tanzania, Ghana, Eritrea, Uganda, Djibouti, and Malawi, but also for countries at different development stages to guide China's future OFDI in the mining industries. The approach reflects the combined experiences from relevant stakeholders (governmental officials, scholars, and mining industrial practitioners), which is critical in decision making. Each of 
the six countries has distinctively different political, economic, regional, production factor, resource endowments and other characteristics. More importantly, the ranking suggests that African countries in the early stages of industrialization constitute the primary target countries for China's OFDI in the immediate future, although countries in the middle stage of industrialization can be closely examined to proceed with care. Countries in the primary production stage are not among the top priority for China's OFDI. The VIKOR approach clearly reveals that China and the African countries at the early stages of industrialization are most complementary in terms of capital, labor, and investment structures. Investing in these countries could potentially yield the highest mutual benefits for both China and the host countries.

Third, by checking the characteristics list of the individual countries, more detailed observation about all the six candidate countries follows. Tanzania is one of the few countries in Africa that enjoys relatively long-term political stability. Tanzania's foreign policy emphasizes non-alignment in the international political arena and has a long-term cooperative relationship with China. China has invested in many fields including mining in Tanzania during the past several decades. According to the Standard and Poor's Global Market Intelligence data, China's investment in Tanzania's mining industries is the largest in Africa. Tanzania has gold, diamond, iron, nickel, uranium, phosphate, coal, natural gas, and other minerals (Table 1). Its mineral resources rank fifth in Africa. China has high demand for many of its mineral resources. Currently, Tanzania is in the early stages of industrialization, with GDP ranking 10th in African countries in 2019. Mining-based heavy industries are the main industries driving its economic growth. The Tanzanian government also attaches great importance to the development of the mining industry. On the other hand, due to financial and technological restrictions, Tanzania is unable to develop its rich mineral resources on its own. The country has a high desire to bring in foreign investors for the development of its mining industries. In addition, Tanzania's infrastructure is relatively complete and can adequately support the development of its mining industry. Tanzania has continuously improved its legal system because of its relative political stability. It has recently classified mining as the most beneficial sector for economic development, provided policy and legal support, and strengthened regulation of resources and environmental protection. All these movements are conducive to the healthy and sustainable development of the mining industry in Tanzania and are healthy signs welcoming OFDI in its mining industries. The VIKOR approach successfully picks Tanzania as the most promising candidate for China's future OFDI in mining industries.

Following Tanzania, Ghana ranked the second most promising candidate via the VIKOR approach. Ghana has a sound political environment. During the past decades, it has actively participated in international organizations, pursued a pluralistic and pragmatic foreign policy and is the second country in sub-Saharan Africa to establish diplomatic relations with China. Ghana is one of the key countries in China's aid to Africa. There are currently close to 200 mining projects invested in Ghana worldwide, but China has fewer mining projects in Ghana and has potential for further cooperation and expansion in Gahan's mining industries. Ghana is rich in mineral resources, including gold, diamonds, bauxite, iron, manganese, oil and gas, and other mineral resources (Table 1). Ghana's economy is growing strongly. Its GDP ranks 9th in 2019 in Africa. However, in Ghana, the service industry accounts for the largest proportion of its economy. The overall level of industrial development remains relatively low. In recent years, the status of industry in its national economy has increased, the Ghanaian government puts a high priority on attracting foreign investment to promote its economic and social development. Mining is a major industry for industrial development, with gold and oil extraction being one of the backbones of Ghana's economy. In recent years, Ghana has continuously improved its infrastructure, strengthened its geological survey to provide more accurate information regarding the country's mineral reserves, and continuously improved its financial environment, which has played a significant role in attracting foreign investment in its mining industry. 
The third ranked country, Eritrea, has a relatively stable political environment and comparably richer mineral resources (Table 1). Eritrea is also one of the relatively developed countries among the six candidates. It is one of the three countries that are in the middle stages of industrialization. The comparably developed status provides better infrastructure conditions and better relevant service sectors supporting the development of mining industries in Eritrea. China has already invested with three mining projects in Eritrea. The accumulated experiences provide invaluable experiments for continuing investment in not only Eritrea, but also other African countries that have similar socioeconomic, cultural, and political environments as Eritrea. The fourth ranked country, Uganda, has an overall locational advantage for being a coastal country that has convenient access to mass ocean transport. Comparing with Tanzania and Ghana, the one downside for Uganda is its relatively unstable political environment since it established its diplomatic relationship with China on 18 October 1962. Uganda's political situation has only stabilized in recent years after Museveni came to power in 1986, ending years of civil war. Still, China and Uganda have maintained a relatively friendly relationship since 1962, which puts Uganda in a position that could potentially attract China's OFDI. In addition, Uganda is a member of many regional and subregional organizations such as the Commonwealth, the NonAligned Movement, the African Union (AU) and the East African Community (EAC). Uganda's global investment environment has risen from 127th in 2019 to 116th in 2020, still a long way to go, but it is on the right track. Uganda is rich in oil, natural gas, mica, feldspar, limestone, phosphate, and other resources, with proven oil reserves of about 6 billion barrels and natural gas of about 14.2 billion cubic meters (Table 1). Uganda's GDP ranks 16th in Africa in 2019. While agriculture is the nation's leading economic sector, Uganda is determined to industrialize with foci on construction and manufacturing industries. Uganda's mining industry is still in the early stages of development and is in an ideal position to receive OFDI from China. As a matter of fact, according to the Uganda Bureau of Statistics, in the 2018/19 fiscal year, Uganda received \$1.02 billion in foreign direct investment, an increase of $130.3 \%$ from the previous fiscal year, with China being the leading country with its investment of \$610 million, accounting for $59.6 \%$ of Uganda's foreign investment. There are currently about 30 mining projects invested in Uganda from around the world, according to the Standard and Poor's Global Market Intelligence data, but China does not have any mining investment projects in Uganda. Investing in Uganda's mining industry will seem to be a logical next step for China's OFDI.

For the other two countries, while the political environment in Djibouti is relatively stable, the political situation in Malawi is less so. Malawi is also the least developed country among the six candidates. Traditionally, China has friendly relations with these two countries and has exchanges and cooperation with these countries for a relatively long time. However, both countries have relatively fewer mineral resources compared with the other four. Djibouti is rich in gold and oil reserves, but relatively poor in other mineral resources, though its geographic location puts it in a relatively advantageous position to receive OFDI and export its products. Malawi, which ranked the least favorable by our VIKOR approach, is constantly in political turmoil, and is getting worse during the global COVID pandemic in the past year. Apparently, these two countries, though having potential for attracting China's OFDI in their respective mining industries, do not come on the top list for China to consider investment in the immediate future based on the combined interested stakeholders' opinions and national characteristics. Our VIKOR approach successfully captures and reflects these facts quite accurately.

The results are interesting in that the analysis reveal that China's current investment locational strategies are not necessarily optimized. Current investment in Eritrea might have poor return. Although the sample size is limited, our survey over the groups of interested stakeholders (governmental officials, scholars, and mining industry practitioners) provides strong participatory evidence to enable a potentially optimized investment location selection strategy in the mining industries in Africa. the proposed AHP-supported VIKOR 
approach is flexible and scalable and can be applied to more than the six countries studied in this research or in similar decision-making scenarios other than mining industries.

\section{Conclusions}

China's industrialization and further development will require more international collaboration and resource imports. Collaboration with and importing from Africa's mineral resources will be critical for China's strategic development in the near future. Currently, the level of China's OFDI in Africa's mining industries is still low and distributed unevenly. Our study suggests that the current locational distribution of China's OFDI is not necessarily optimized when multiple and conflicting criteria are taken into consideration. The evaluating indicators collected in this study and the AHP-supported VIKOR approach seem to provide a relatively holistic assessment of China's potential OFDI projects in Africa, considering relevant stakeholder and experts' opinions. The results obtained from the VIKOR approach reflect the fact that in current Africa, while the gains from investing in the abundant mineral resources could be potentially huge because of the mineral reserves, risks from unstable geopolitical struggles, governmental stability, environmental regulation, and other factors might prevent China's immediate OFDI in the mining industries in some of the countries. This especially applies to countries that have relatively unstable political environments and lower economic development levels, such as Malawi. The VIKOR approach provides a multi-dimensional evaluation tool that could be effective for future investment decision making. Furthermore, we contend that these indicators can serve as a benchmark and starting point for China's OFDI decision making. The experts opinion-embedded AHP approach suggests that political stability has the greatest weight among the six groups of evaluating criteria, followed by resource endowment and value, economic environment, infrastructure, geological preparation, and legal environment. Political stability is a guarantee for the returns of long-term investment such as investment in the mining industries. Apparently, these weights and rankings will likely change over time as China accelerates the implementation of its Belt and Road Initiative, and as African countries continue to develop. This study also provides an empirical exploration to develop and strengthen the theory of location selection of OFDI, which might serve as a model for multi-criteria decision-making processes in other fields. For our next research endeavor, we will attempt to acquire data from more African countries to further verify the approach and expand the scope of the study.

Author Contributions: Conceptualization, X.W. and D.Y.; methodology, X.W. and D.Y.; validation, X.W., D.Y. and C.Y.; formal analysis, X.W.; investigation, X.W.; resources, X.W., D.Y. and C.Y.; data curation, X.W.; writing-original draft preparation, X.W. and D.Y.; writing-review and editing, D.Y.; visualization, X.W.; supervision, D.Y. and C.Y.; project administration, X.W. and D.Y. All authors have read and agreed to the published version of the manuscript.

Funding: This research receives no external funding.

Institutional Review Board Statement: Not applicable.

Informed Consent Statement: Not applicable.

Data Availability Statement: Data available upon request.

Conflicts of Interest: The authors declare no conflict of interest.

\section{References}

1. Yu, D.; Murakami, D.; Zhang, Y.; Wu, X.; Li, D.; Wang, X.; Li, G. Investigating high-speed rail construction's support to county level regional development in China: An eigen-vector based spatial filtering panel data analysis. Transp. Res. Part B Methodol. 2020, 133, 21-37. [CrossRef]

2. Chen, Y.; Wei, L.J. Railroad development, temporal-spatial externalities, and growth spillover: Theory and empirical evidence. J. Reg. Sci. 2018, 58, 980-1002. [CrossRef] 
3. Fan, J.; Wang, Y.; Ouyang, Z.; Li, L.; Xu, Y.; Zhang, W.; Wang, C.; Xu, W.; Li, J.; Yu, J.; et al. Risk forewarning of regional development sustainability based on a natural resources and environmental carrying index in China. Earth's Future 2017, 5 , 196-213. [CrossRef]

4. Zhou, D.; Xu, J.C.; Lin, Z.L. Conflict or coordination? Assessing land use multi-functionalization using production-living-ecology analysis. Sci. Total Environ. 2017, 577, 136-147. [CrossRef] [PubMed]

5. Fang, C.; Yu, D. Urban agglomeration: An evolving concept of an emerging phenomenon. Landsc. Urban Plan. 2017, 162, 126-136. [CrossRef]

6. Lu, S.; Guan, X.; Yu, D.; Deng, Y.; Zhou, L. Multi-Scale Analysis of Regional Inequality based on Spatial Field Model: A Case Study of China from 2000 to 2012. ISPRS Int. J. Geo-Inf. 2015, 4, 1982-2003. [CrossRef]

7. Yu, D. Understanding regional development mechanisms in Greater Beijing Area, China, 1995-2001, from a spatial-temporal perspective. GeoJournal 2013, 79, 195-207. [CrossRef]

8. Li, G.; Fang, C. Analyzing the multi-mechanism of regional inequality in China. Ann. Reg. Sci. 2014, 52, 155-182. [CrossRef]

9. Liu, Y.; Yang, C. Strategic coupling of local firms in global production networks: The rise of the home appliance industry in Shunde, China. Eurasian Geogr. Econ. 2013, 54, 444-463. [CrossRef]

10. Athukorala, P.C. Production Networks and Trade Patterns in East Asia: Regionalization or Globalization? Asian Econ. Pap. 2011, 10, 65-95. [CrossRef]

11. Cusmano, L.; Mancusi, M.L.; Morrison, A. Globalization of Production and Innovation: How Outsourcing is Reshaping an Advanced Manufacturing Area. Reg. Stud. 2010, 44, 235-252. [CrossRef]

12. Mahutga, M. Production Globalization and the Segmentation of the Global Manufacturing Sector. Sociol. Dev. 2020, 6, 275-295. [CrossRef]

13. Wei, Y.D.; Yu, D. State policy and the globalization of Beijing: Emerging themes. Habitat Int. 2006, 30, 377-395. [CrossRef]

14. Utesch-Xiong, F. China's OFDI policy announcements and cross-border M\&A. Int. J. Emerg. Mark. 2021, 21. [CrossRef]

15. Hofman, I. Politics or profits along the "Silk Road": What drives Chinese farms in Tajikistan and helps them thrive? Eurasian Geogr. Econ. 2016, 57, 457-481. [CrossRef]

16. Liu, Y.L.; Ge, Y.J.; Hu, Z.D.; Wang, S.F. Culture and capital flows-Exploring the spatial differentiation of China's OFDI. China Econ. Rev. 2018, 48, 27-45.

17. Ramasamy, B.; Yeung, M. China's outward foreign direct investment (OFDI) to developing countries: The case of Central and Eastern Europe (CEE). J. Asia Pac. Econ. 2020, 23, 1-23. [CrossRef]

18. Zhao, T. National distance and China's OFDI: Research based on the 'Belt and Road' countries. Appl. Econ. Lett. 2021, 28, 835-839.

19. Lu, F.; Liu, X. Africa's industrialization and China's OFDI in the manufacturing sector: Rationales and practices. China Econ. J. 2018, 11, 126-150. [CrossRef]

20. Rapanyane, M.B.; Shai, K.B. China's multinational corporations in the Democratic Republic of Congo's mining industry: An Afrocentric critique. J. Public Aff. 2020, 20,7.

21. Ericsson, M.; Löf, O.; Löf, A. Chinese control over African and global mining_past, present and future. Miner. Econ. 2020, 33, 153-181. [CrossRef]

22. Stuermer, M. Industrialization and the demand for mineral commodities. J. Int. Money Financ. 2017, 76, 16-27. [CrossRef]

23. Sommer, J.M.; Restivo, M.; Shandra, J.M. China, Mining, and Forests: A Cross-National Test of Ecologically Unequal Ex-change. Sociol Q. 2021, 62, 369-391.

24. de Mendonca, M.G.; Abrao, R.A.F. South Africa's dependence on mineral exports in its relations with China: The road to de-industrialization? Relac. Int. 2017, 26, 165-190.

25. Christensen, D. Concession Stands: How Mining Investments Incite Protest in Africa. Int. Organ. 2019, 73, 65-101. [CrossRef]

26. Harvey, D. The spatial fix-Hegel, von thunen, and marx. Antipode 1981, 13, 1-12. [CrossRef]

27. von Thünen, J. The Isolated State; Pergamon Press: Oxford, UK, 1966.

28. McCann, P.; Sheppard, S. The Rise, Fall and Rise Again of Industrial Location Theory. Reg. Stud. 2003, 37, 649-663. [CrossRef]

29. Scheuplein, C. "A geographically determined system of economics": Concepts of space and location theories in economic historicism. Erdkunde 2007, 61, 225-238.

30. Isard, W. The General Theory of Location and Space-Economy. Q. J. Econ. 1949, 63, 476. [CrossRef]

31. Dunning, J.H.; Pitelis, C.N. Stephen Hymer's contribution to international business scholarship: An assessment and extension. J. Int. Bus. Stud. 2008, 39, 167-176.

32. Dunning, J.H. The Eclectic (OLI) Paradigm of International Production: Past, Present and Future. Int. J. Econ. Bus. 2001, 8, 173-190. [CrossRef]

33. Buckley, P.J.; Casson, M. The Future of the Multinational Enterprise; Springer: Berlin/Heidelberg, Germany, 1976 ; pp. 32-65.

34. Ding, Z.F.; Sun, G.J. Examination of China's outward foreign direct investment under the background of One Belt One Road. J. Sichuan Norm. Univ. Soc. Sci. Ed. 2016, 2.

35. Huang, C.; Chen, Y. Spatiotemporal evolution of China's Investments to the US since 2000. World Geogr. Res. 2016, $25,40-49$.

36. Kelley, D.; Coner, J.K.; Lyles, M.A. Chinese foreign direct investment in the United States: Location choice determinants and strategic implications for the State of Indiana. Bus. Horizons 2013, 56, 443-451. [CrossRef]

37. Wang, J. Studies of the Location Evaluation and Countermeasure of the "Belt and Road" National Direct Investment by Coal Enterprises; Taiyuan Institute of Science and Technology: Taiyuan, China, 2019. 
38. Wu, H. Study on the Location Selection of Foreign Direct Investment by Chinese Copper Mining Enterprises; Shanxi University of Finance and Economics: Taiyuan, China, 2015.

39. Jiang, Y. Study on the Location Selection of OFDI in China's Mining Industry; Nanjing University of Agriculture: Nanjing, China, 2015.

40. Liu, W. Study on the Influence Factors of the Location Selection of OFDI of Chinese Energy Enterprises; Hubei University: Wuhan, China, 2018.

41. Xue, Y.R.; Zhang, H.L.; Zou, P. Ownership Differences, Arbitrage Motivation and Location Decision-Making of Foreign Direct Investment-Based on the Analysis of Mineral Resources State-Owned Enterprises Economic Review. Econ. Rev. 2016, 2, 137-150.

42. Tholana, T.; Musingwini, C.; Njowa, G. An algorithm to construct industry cost curves used in analysing cash cost performance of operations for selected minerals in South Africa. J. S. Afr. Inst. Min. Metall. 2013, 113, 473-484.

43. Chenery, H.; Syrquin, M. Industrialization and Growth: A comparative Study; Oxford University Press: London, UK, 1986; Chapter 3; pp. 37-83.

44. Opricovic, S.; Tzeng, G.-H. Compromise solution by MCDM methods: A comparative analysis of VIKOR and TOPSIS. Eur. J. Oper. Res. 2004, 156, 445-455. [CrossRef]

45. Opricovic, S.; Tzeng, G.-H. Extended VIKOR method in comparison with outranking methods. Eur. J. Oper. Res. 2007, 178, 514-529. [CrossRef]

46. Dunning, J.H. The eclectic paradigm of international production: A restatement and some possible extensions. In The Eclectic Paradigm; Cantwell, J., Ed.; Palgrave Macmillan: London, UK, 2015; pp. 80-84. [CrossRef]

47. Jackson, S.L.; Dear, D. Resource extraction and national anxieties: China's economic presence in Mongolia. Eurasian Geogr. Econ. 2016, 57, 343-373. [CrossRef]

48. Rubbers, B. Governing new mining projects in D. R. Congo. A view from the HR department of a Chinese company. Extr. Ind. Soc. 2020, 7, 191-198. [CrossRef]

49. Rubbers, B. Mining Boom, Labour Market Segmentation and Social Inequality in the Congolese Copperbelt. Dev. Change 2020, 51, 1555-1578. [CrossRef] [PubMed]

50. Yasuda, N.; Kotabe, M. Political risks and foreign direct investments by multinational corporations: A reference point approach. Glob. Strateg. J. 2021, 11, 156-184. [CrossRef]

51. Sauerwein, T. Gold mining and development in Côte d'Ivoire: Trajectories, opportunities and oversights. Land Use Policy 2020, 91, 104323. [CrossRef]

52. Fu, B.; Yu, D.; Zhang, Y. The livable urban landscape: GIS and remote sensing extracted land use assessment for urban livability in Changchun Proper, China. Land Use Policy 2019, 87, 104048. [CrossRef]

53. Yu, D.; Fang, C. The dynamics of public safety in cities: A case study of Shanghai from 2010 to 2025. Habitat Int. 2017, 69, 104-113. [CrossRef]

54. Yu, D.; Fang, C.; Xue, D.; Yin, J. Assessing Urban Public Safety via Indicator-Based Evaluating Method: A Systemic View of Shanghai. Soc. Indic. Res. 2013, 117, 89-104. [CrossRef]

55. Saaty, T.L. How to Make a Decision: The Analytic Hierarchy Process. Inf. J. Appl. Anal. 1994, 24, 19-43. [CrossRef]

56. Saaty, T.L. Perspectives on the Theory and Practice of Decision Making with the Analytic Hierarchy Process. Int. J. Serv. Sci. 1994, 1, 83. [CrossRef]

57. Saaty, T.L. Decision-making with the AHP: Why is the principal eigenvector necessary. Eur. J. Oper. Res. 2003, 145, 85-91. [CrossRef]

58. Shanxi Meta Decision Software and Technology LLC. YAAHP Analytic Hierarchical Process Software, version 10.0 6; Shanxi Meta Decision Software and Technology LLC.: Taiyuan, China, 2017.

59. Ignat'Ev, S.; Lukonin, S. China's Investment Relations with African Countries. World Econ. Int. Relat. 2018, 62, 5-12. [CrossRef]

60. Cooke, F.L.; Wang, J.; Yao, X.; Xiong, L.; Zhang, J.; Li, A.S. Mining with a high-end strategy: A study of Chinese mining firms in Africa and human resources implica-tions. Int. J. Hum. Resour. Manag. 2015, 26, 2744-2762. [CrossRef]

61. Kaplinsky, R.; Morris, M. The Power of the Chinese Dragon; Springer: Berlin/Heidelberg, Germany, 2016 ; pp. 123-148. 